\title{
ILS vs. DBMS in Latin American Web OPACs: Discriminant Analysis Applied to User Interface
}

\author{
Elsa Barber \\ Silvia Pisano \\ Sandra Romagnoli \\ Verónica Parsiale \\ Gabriela de Pedro \\ Carolina Gregui \\ Nancy Blanco \\ Instituto de Investigaciones Bibliotecológicas, Facultad de Filosofía y \\ Letras, Universidad de Buenos Aires
}

\section{Introduction}

This chapter reports on the research project "Online Public Access Catalogs (OPACs) in Mercosur" Project F054, (UBACYT Scientific Program 20042007, Universidad de Buenos Aires). The aim of the project was to investigate the use of new information technologies in libraries in a selected geographical grouping. The project revealed that only minimal services were available through most online public access catalogs in libraries of Mercosur member and associate countries. Further, the survey indicated that many of them were in an early stage of implementation (Barber et al. 2006, 2007a, 2007b, 2008). According to international trends catalog functions should be based on user needs. Consequently, results provided by this research offer relevant information that could be taken into account by libraries in the region when software and functionalities were being evaluated and/or considered.

Given the many challenges that libraries face in the information age, the aim of Project F036 - "Online public access catalogs (OPACs) in Latin America" $^{2}$ (UBACYT Scientific Program 2008-2010, Universidad de Buenos Aires)

1 The Mercosur countries are Argentina, Brazil, Paraguay and Uruguay. Bolivia, Chile, Ecuador, Peru and Venezuela have associated status with this political grouping.

2 For the purposes of this survey and findings presented in this chapter the following countries compromise the group known as Latin America: Argentina, Bahamas, Barbados, Belize, Bolivia, Brazil, Chile, Columbia, Costa Rica, Cuba, Ecuador, El Salvador, French Guiana, Guatemala, Jamaica, Mexico, Nicaragua, Panama, Paraguay, Peru, Puerto Rico, Suriname, Trinidad and Tobago, Uruguay and Venezuela. 
was-see if it was possible to extend the findings of Project F054 in Mercosur countries to the rest of Latin America. In addition, Project F036 focused on an analysis of user interface of Web OPACs ${ }^{3}$ in university, special, public and national libraries with a view to establishing differences among them depending on whether they had chosen an Integrated Library Systems (ILS) or Database Management Systems (DBMS). This chapter presents the results of a survey of Project F036.

Project F036 provides primary data and increases knowledge on a key aspect of access and use of information a region that of several developing countries (see footnote 2). Moreover, Project F036 provides a methodological tool that could be used to study similar situations in other regions.

\section{Theoretical Framework}

Since the eighties, when the use of OPACs began to spread (Kaske and Ferguson 1980), several studies were conducted, the findings of which described and compared existing OPAC features in relation to user interface (Hildreth 1982, 1985; Matthews 1982). Similarly, from the 1980s onwards efforts were devoted to the design of third generation catalogs (Kaske and Ferguson 1980; Williamson 1982; Clifford 1987; Hildreth 1987, 1988; Culkin 1989; McGarry and Svenonius 1991; Frost, 1994; Larson et al. 1996; Stevens 1998; Delsey 2001; Byrum 2005). Since the 1990s, as a result of this ongoing research several recommendations have been made with regard to improving OPACs, three of which will be mentioned:

1. Improvement of database records;

2. Search capability; and

3. Interface design.

Researchers commenting on these areas include Hildreth 1995, 2001; Beaulieu and Borgman, 1996; Large and Beheshti 1997. Yee (1991) warned that search methods, indexing and format display as well as data relations and structure all relate to user interface. Experts focused their attention on some specific issues relating to user interface, but not as much on the functionalities of components in OPACs (Hildreth 1995; Borgman 1996; Beaulieu 2000).

In order to increase the level of the usability of OPACs, conversational as well as object oriented interfaces have been considered either as opposite (Chiang 1991), or, as two sides of communication able to complement each other to deliver solutions (Henry 1991). But such developments would take into account other issues such as human-computer interaction and the design of inter-

3 As all the OPACs in this study are situated in the Web, hereafter they will only be referred to as OPACs. 
faces suited to resolve different tasks (Hildreth 1988, 2001; Henry 1991; Carlyle 1996; Shneiderman 1998; Beaulieu 2000; Gremett 2006; Komlodi et al. 2006; Meadow et al. 2007). Design should be intuitive; and, context needs to be considered, especially the Internet, where direct user assistance is restricted (Bates 1991; Shneiderman 1998; Wildemuth 2006). According to some authors, design should be able to accommodate a wide range of user search behavior patterns in libraries and not only in catalogs (Beheshti et al. 1996).

In the beginning, first and second generation catalogs offered menu-driven or command-driven interfaces. Due to their limitations, some projects (OKAPI in England; MELVYL in the University of California, among others) began to evolve into a more interactive system through the use of heuristic algorithms that, even when they were not completely successful, led the way to the next generation of OPACs (Clifford 1987). Williams et al. (1986) examined, in this sense, the associative interface where terms entered by users were systemassociated with other terms to identify additional potentially relevant documents or to delimit results if precision was too low.

Williams et al. (1995) also referred to graphical user interface (GUI); whereas Yee and Layne (1998) made reference to form fill-in, client-server and Web interfaces. Dowling (1997) pointed out that despite the "technological immaturity" of many OPACs, their implementation in the Web was the best option for libraries. In the Statement of International Cataloguing Principles (IFLA 2009) functions of the catalog were updated and described as being: to find, to identify, to select, to obtain, and, to navigate. On this basis, bibliographic services undertook new initiatives to increase the value of online catalogs (Byrum 2005). Beheshti's (2003) view was that even when OPACs were implemented using client-server platforms, Z39.50 Protocol and links to other resources, they continued to be non-integrated systems to information resources.

Software developments designed to overcome the above-mentioned limitations were based on the design of an integrated system which acted like a portal that could perform searches through multiple databases (Thomas 2000; Arant and Payne 2001; Beheshti 2003; Dorner and Curtis 2003; Library of Congress. Portals Applications Issues Group 2005). A tool with such features would demand a common user interface, similar to the one proposed by Boss (2005). Recent research considers bibliographic records display in OPACs and available on the Web (Cherry and Cox 1996; Carlyle and Timmons 2002). Ayres et al. (1999) started the project, "BOPAC2", to test and evaluate Web interfaces that made uniform access to online catalogs through Z39.50 Protocol possible.

In Ibero-America ${ }^{4}$ some authors explored users' attitude towards online catalogs since they were first introduced in universities (Martínez-Arellano

4 This is a collective term that describes those countries in Latin America which were former colonies of Spain and Portugal. 
1996; Villén-Rueda et al. 2007). On the other hand, other authors reflected on the underlying problems in catalogs despite the significant improvements that had been made in user interfaces (Ortíz Repiso and Moscoso 1999; Rodríguez Yunta and Giménez Toledo 2005). Herrero Solana and Moya Anegón (2001) used Cherry and Cox's (1996) criteria and applied the multivariate analysis to 25 Latin American OPACs.

From the above mentioned precedents and given that Project F036 did not have the initial aim of evaluating implemented systems or suggesting guidelines for their design but to describe their functionalities, the checklists developed by Cherry and Cox (1996) and by Abadal Falgueras (2002) as well as the guidelines for displays in OPACs (Yee 1998) were not used. Criteria applied by Dorner and Curtis (2003) to compare and evaluate library portals were not used either, because they had been conceived to analyze different objects of study, not yet present in most Latin American libraries.

Instead, the criteria developed by Hildreth (1982) proved to be appropriate tools to examine the features of OPACs interfaces even though they had been conceived to observe online catalogs in situ. Besides, their categories of analysis had been chosen to carry out some other descriptive and comparative studies (Zumer and Zeng 1994; Badu and O'Brien 2000; Ramesh Babu and Tamizhchelvan 2003; Játiva Miralles 2004). Upon the application of this checklist and statistical tests performed in a second stage, the resulting hypothesis was software type influenced the presence/absence of all surveyed functions and that there were differences in OPACs depending on the software chosen by Latin American countries.

\section{Research Methodology}

A quantitative methodology was chosen to analyze the object of the study. A country and type of library search was therefore done of online OPACs that are available on the Internet. The OPACs investigated by the researchers were free and did not require password access. The resulting directory was refined to exclude unavailable catalogs and those leading only to lists of works. As OPACs were the delimiting units of analysis, Web catalogs belonging to networks or library systems were counted as a single unit even though when they provided access to multiple institutions.

Analysis began with information obtained from a sample of 846 units which was based on the previously mentioned inclusion/exclusion criteria grouped in different strata:

\section{Country:}

Argentina: 125 units $-14.8 \%$

Brazil: 147 units $-17.4 \%$ 
Paraguay: 9 units $-1.1 \%$

Uruguay: 16 units $-1.9 \%$

Bolivia: 18 units $-2.1 \%$

Chile: 71 units $-8.4 \%$

Colombia: 64 units $-7.6 \%$

Ecuador: 28 units $-3.3 \%$

Peru: 55 units $-6.5 \%$

Venezuela: 34 units $-4.0 \%$

Bahamas: 2 units $-0.2 \%$

Barbados: 3 units $-0.4 \%$

Belize: 1 unit $-0.1 \%$

Costa Rica: 25 units $-3.0 \%$

Cuba: 12 units $-1.4 \%$

El Salvador: 16 units $-1.9 \%$

Guatemala, 19 units $-2.2 \%$

French Guiana: 5 units $-0.6 \%$

Jamaica: 4 units $-0.5 \%$

Mexico: 138 units $-16.3 \%$

Nicaragua: 15 units $-1.8 \%$

Panama, 12 units $-1.4 \%$;

Puerto Rico: 23 units - 2.7\%

Suriname: 1 unit $-0.1 \%$

Trinidad \& Tobago: 3 units $-0.4 \%$

Type of Library:

National: 14 units $-1.7 \%$

Public: 29 units $-3.4 \%$

University: 532 units $-62.9 \%$

Special: 271 units $-32.0 \%$

Type of software:

International: 177 units $-20.8 \%$

Regional: 121 units $-14.3 \%$

ISIS: 139 units $-16.4 \%$

Others (local developments): 109 units - 12.9\%

Unidentified: 300 units $-35.5 \%$

Due to the considerable variety of software used by units, software type was grouped in 5 categories:

International:

Commercial systems developed mainly in the United States and European countries (ALEPH, Unicorn, Alephino, VTLS, InMagic, Glas, Logicat); 


\section{Regional:}

Latin American commercial systems (Pergamum and Potiron, Brazil; Pérgamo, Argentina; Alejandría and Ms Info, Venezuela; SIABUC, Mexico; GLIFOS, Guatemala);

ISIS:

Considered as a category itself although it is not strictly an integrated software system but rather it is a database management system;

\section{Others:}

Ad hoc systems or locally developed systems not widely used;

\section{Unidentified:}

Systems that could not be identified based on observation/use of the OPAC interface.

For data collection, the checklist created by Hildreth (1982) was used after being updated and limited according to current trends to 38 closed questions. This guide included 4 areas:

Area I: Operational control;

Area II: Search formulation control and Access points;

Area III: Output control; and

Area IV: User assistance: information and instruction.

The functions included in each area are listed below:

Area I: Operational control - default function, select function, select file, default values, dialogue levels, edit search query, combine commands, refine search statement;

Area II: Search formulation control - derived search keys, access to authority catalog, free text search in selected fields, free text search in entire record, restrict search results, Boolean search, Boolean search in selected fields, Boolean search in entire record, relational operators, truncation, proximity operators; Access points - author, title and subject search;

Area III: Output control - select a format for display, select records, select results order, print results online, save and/or mail results; and

Area IV: User assistance: information and instruction - list of files, list of access points, list of commands, index terms, search history, item location, item availability, system messages, procedural prompts, help messages, online tutorials.

Data was collected through direct observation of 846 OPACs between 2006 and 2009. The resulting information was analyzed and interpreted. The percentage of functionalities present was calculated for Mercosur (member and 
associate countries) and Latin America countries. After this, capabilities were compared according to type of software through tests of independence. The same test was applied to compare type of software in countries represented in the sample by 30 or more cases. Software types were also compared in different areas using multiple discriminant analysis. It was then possible to establish the characteristics of surveyed OPACs interfaces according to software types in order to determine group membership in accordance with area functionalities. Categories were regrouped in the original variable "Type of software" to improve prediction depending on the use of ILS or DBMS.

\section{Results and Discussion}

As was previously noted, a considerable number of the libraries that were surveyed in Mercosur (member and associate) countries were not operating on an ILS but rather they were using a DBMS belonging, for example, to the ISIS family (Barber 2007a, 2007b, 2008). Despite the negative impact of this (i. e. usage of DBMSs vs. ILSs) on the development of information units and their possibilities to participate in international cooperation, the distribution of ILS systems as compared to that of DBMS, had never been studied before. This is why previously it was believed that only $35.1 \%$ of libraries were using an ILS, even though it had been observed that the frequency of use of international and regional software (ILS in both cases) had increased in Latin America to a larger extent than other types of software (Table I). This difference could not reverse the trend already identified in that survey, which is a precedent of this analysis.

On the other hand, it has been verified that many libraries had chosen to adopt either ad-hoc systems or locally developed products. In those few libraries which used locally developed products it was noted that those systems had limited functionalities and many of them had not been updated. Based on the methodology used in this research - and examination of OPAC interfaces found on the Internet, it has not been possible to identify the system running behind many OPAC systems. According to the results obtained, the functionalities of these systems were limited, interface design minimalist to a degree which tended to compromise the information retrieval.

The outstanding features of the user interface of Latin American OPACs are explained next and compared with those that were surveyed in previous research that took place in the Mercosur community. In Area I - Operational control (Table 2), results for general functionalities available when starting an OPAC session were quite similar in Mercosur and Latin American libraries. Libraries in both regions showed a predominant trend to provide users on one hand with an initial default function instead of giving them the choice to select the desired function. On the other hand, information was organized into sepa- 
324 Elsa Barber et al.

\begin{tabular}{|c|c|c|c|c|}
\hline \multirow[t]{2}{*}{ Software } & \multicolumn{2}{|c|}{ Frequency } & \multicolumn{2}{|c|}{ Percentage } \\
\hline & Mercosur & Latin Am. & Mercosur $\%$ & Latin Am.\% \\
\hline \multicolumn{5}{|l|}{ International } \\
\hline ALEPH & 31 & 100 & 5.5 & 11.8 \\
\hline Alephino & 1 & 1 & 0.2 & 0.1 \\
\hline Glas & 1 & 3 & 0.2 & 0.4 \\
\hline Inmagic & 2 & 3 & 0.4 & 0.4 \\
\hline Unicorn & 12 & 22 & 2.1 & 2.6 \\
\hline VTLS & 6 & 6 & 1.1 & 0.7 \\
\hline Dynix & 9 & 18 & 1.6 & 2.1 \\
\hline Webcat & 4 & 5 & 0.7 & 0.6 \\
\hline Absysnet & 2 & 8 & 0.4 & 0.9 \\
\hline Sabini & 1 & 1 & 0.2 & 0.1 \\
\hline Olib & 8 & 9 & 1.4 & 1.1 \\
\hline \multicolumn{5}{|l|}{ Regional } \\
\hline Aguapey & 2 & 2 & 0.4 & 0.2 \\
\hline Pérgamo & 5 & 5 & 0.9 & 0.6 \\
\hline Pergamum & 31 & 31 & 5.5 & 3.7 \\
\hline Potiron & 3 & 3 & 0.5 & 0.4 \\
\hline Janium & 5 & 10 & 0.9 & 1.2 \\
\hline Alejandria & 8 & 10 & 1.4 & 1.2 \\
\hline Ms Info & 12 & 12 & 2.1 & 1.4 \\
\hline SIABUC & 1 & 33 & 0.2 & 3.9 \\
\hline GLIFOS & -- & 16 & -- & 1.9 \\
\hline \multicolumn{5}{|l|}{ ISIS } \\
\hline MINISIS & 1 & 1 & 0.2 & 0.1 \\
\hline OPWISIS & 4 & 6 & 0.7 & 0.7 \\
\hline WINISIS & 111 & 131 & 19.6 & 15.5 \\
\hline Others & 71 & 111 & 12.5 & 13.1 \\
\hline Unidentified & 236 & 299 & 41.6 & 35.3 \\
\hline Total & 567 & 846 & 100.0 & 100.0 \\
\hline
\end{tabular}

Table 1: Software 
rate databases, according to format or library owning the resource. In Latin America, percentages sometimes increased significantly in variables that allowed one to exert control over the search process, like those that made it possible to select dialog levels, edit and refine a search statement or stack commands.

\begin{tabular}{lcc} 
Functionalities & Latin America & Mercosur \\
\hline Default function & $79.1 \%$ & $79.2 \%$ \\
Select function & $32.0 \%$ & $36.0 \%$ \\
Select file & $63.4 \%$ & $67.5 \%$ \\
Default values & $20.9 \%$ & $22.2 \%$ \\
Dialogue levels & $51.9 \%$ & $46.0 \%$ \\
Edit search query & $47.9 \%$ & $42.2 \%$ \\
Combine commands & $31.2 \%$ & $17.1 \%$ \\
Refine search statement & $27.3 \%$ & $17.6 \%$
\end{tabular}

Table 2: Area I, operational control

For Area II - Search formulation control and access points (Table 3) it was noted in most cases that Latin American libraries did not give access to the authority catalog even though they had implemented integrated library systems in a proportionally higher percentage of institutions. Yet, the same trend observed in Area I concerning a greater presence of functionalities offering search alternatives through search operators and preset access points, was also verified in Latin American OPACs.

Nevertheless, only 8 out of 14 functionalities analyzed in this area were present in more than $50 \%$ of Latin American OPACs and only 7 in more than $50 \%$ of OPACs in the Mercosur grouping (Table 3). This proved to be a very significant fact as higher frequencies were obtained in basic applications (full text search or Boolean search) and in basic access points (author, title, subject).

Options that allowed one to refine search results were found in a limited number of user interfaces due to the low presence of functionalities with this capability and the lowest percentage in the use of search delimiters, proximity operators and derived search keys.

The capability of customizing display formats and manipulating search results are functionalities which clearly demonstrate the capacity of OPACs to meet different user demands. As previously seen in operational control and search formulation, percentages indicating the presence of functionalities belonging to this area were higher in Latin American than in Mercosur countries 


\begin{tabular}{|c|c|c|}
\hline Functionalities & Latin America\% & Mercosur\% \\
\hline Derived search keys & 2.4 & 3.4 \\
\hline Access to authority catalog & 8.2 & 10.9 \\
\hline $\begin{array}{l}\text { Free text search in selected } \\
\text { fields }\end{array}$ & 84.2 & 81.0 \\
\hline $\begin{array}{l}\text { Free text search in entire } \\
\text { record }\end{array}$ & 71.7 & 62.8 \\
\hline Restrict search results & 40.7 & 32.8 \\
\hline Boolean search & 68.0 & 66.3 \\
\hline $\begin{array}{l}\text { Boolean search in selected } \\
\text { fields }\end{array}$ & 61.5 & 57.3 \\
\hline Boolean search in entire record & 53.2 & 45.3 \\
\hline Relational operators & 11.3 & 9.5 \\
\hline Truncation & 39.6 & 33.9 \\
\hline Proximity operators & 15.7 & 14.5 \\
\hline Author & 91.1 & 90.1 \\
\hline Títle & 90.4 & 89.2 \\
\hline Subject & 85.3 & 84.7 \\
\hline
\end{tabular}

Table 3: Area II - Search formulation control and access points

(Area III - Output control, Table 4). However, these were slightly higher than $50 \%$ in selecting records for display. Online printing, mailing or saving results were implemented in only $35 \%$ of the OPACs.

\begin{tabular}{|l|c|c|}
\hline Functionalities & Latin America\% & Mercosur\% \\
\hline Select a format for display & 44.3 & 39.0 \\
\hline Select records & 71.0 & 63.5 \\
\hline Select results order & 33.5 & 26.5 \\
\hline Print results online & 34.9 & 34.2 \\
\hline Save and/or mail results & 32.0 & 24.7 \\
\hline
\end{tabular}

Table 4: Area III - Output control

Finally, giving access to the collection through separate databases showed a major trend in Area IV (User assistance: information and instruction, Table 5) in Mercosur countries. In addition, it was verified that less than $50 \%$ of Latin 
American interfaces included key user assistance functions such as displaying indexes, search history or item availability. Only three functionalities were present in more than half of the OPACs surveyed and the percentage of occurrences of system help messages or search formulation or refining was very low.

\begin{tabular}{l|c|c|}
\hline Functionalities & Latin America\% & Mercosur\% \\
\hline List of files & 43.1 & 50.6 \\
\hline List of access points & 63.8 & 59.4 \\
\hline List of commands & 26.2 & 15.2 \\
\hline Index terms & 45.4 & 38.4 \\
\hline Search history & 20.4 & 13.2 \\
Item location & 88.2 & 86.2 \\
Item availability & 48.1 & 39.5 \\
\hline System messages & 68.6 & 57.0 \\
Procedural prompts & 21.7 & 19.2 \\
Help messages & 42.2 & 33.5 \\
\hline Online tutorials & 3.2 & 3.5 \\
\hline
\end{tabular}

Table 5: Area IV - User assistance: information and instruction

In general, it was found that 23 of 38 functionalities in the libraries that were surveyed in Latin America showed a presence in lower than $50 \%$ of the OPACs investigated. A similar trend was found in Mercosur (member and associate countries) where 24 out of 38 functions were available in less than $50 \%$ of Web OPAC interfaces (Tables 2, 3, 4 and 5). Deficiencies were found not only in the number of functionalities but in their quality as well. Analysis revealed that the absent functions were exactly those that had the capability of providing feedback and refining strategies. This meant that libraries in the region did not provide their user communities with comprehensive access to their collections because of the limitations of their OPAC resources to retrieve works from their catalogs.

When establishing the relationship between the presence of the studied functionalities in user interface and the type of software used by information units in the Latin American region as a whole (Chi-square test: Type of software vs. Functionalities, Table 6) it was noted that even though fewer in number, international integrated library systems (Table 6, column I) more frequently offered functionalities that led to more precise and user-customized search and retrieval results. On the other hand, applications which were mainly 
found in underdeveloped interfaces were especially predominant in non identified systems (Table 6 , column $U$ ). These peculiarities led to significantly high values $(p<0.0001)$ in 31 out of 38 functionalities when applying a chi-square test in the sample to verify the association between the above mentioned variables.

In areas linked to operational control and output, the presence/absence of all functionalities was directly associated with the type of software. In Area II, author, title and subject access points did not show any association as they are usually provided access points in both ILS and DBMS. Generally, the use of derived search keys, even though less frequent, was not associated with the type of software. In Area IV, neither search commands nor tutorials were frequently offered as a help option. This proved to be non-significant after applying the test of independence.

The presence of an initial default function was clearly associated to systems classified under the unidentified software category. On the contrary, the capability of selecting the desired function or database was predominant in international software. In this case, it was notable that larger differences were found in relation to "Regional", "ISIS" and "Others". Differences between international software and all others were even greater in the other functionalities belonging to this area. However, some peculiarities could be observed such as a more frequent presence of default values for the session, the possibility to edit and refine the search statement or to combine commands especially in "ISIS" and "Unidentified" over "Regional" and "Others" which were associated to a very low presence of these functionalities.

In Area II - access to the authority catalog was, in this sample, first associated with regional software and secondly, with international software being nearly absent in the other strata. Full text search in selected fields was a highly present functionality in every stratum even though it was particularly associated to the unidentified software. International software was clearly ahead of the rest in all other functionalities. Full text search in entire record, restriction of search results, the use of Boolean operators in selected fields and truncation were functions associated with "Unidentified" and "ISIS" strata over "Regional" and "Others". The implementation of search delimiters and proximity operators was found in regional software and less in each one of the other strata reaching the lowest percentage in "Unidentified" software.

Regarding system flexibility to allow users to customize their results display as well as using them according to their needs, the international software was considerably advanced over the rest of the strata in relation to printing, saving and mailing results. Distance decreased between this stratum and "Unidentified" when evaluating the behavior of the function "Select records for display" which, moreover, obtained the higher results for this area. Strata "Regional", "ISIS" and "Others" distinguished from each other in descending order in all the functionalities in the area except in "Sort results for display" 


\begin{tabular}{|c|c|c|c|c|c|c|}
\hline Area I & $\mathrm{I}$ & $\mathrm{R}$ & IS & $\mathrm{O}$ & $\mathrm{U}$ & $p$ \\
\hline Default function & 16.7 & 9.5 & 14.2 & 8.4 & 27.1 & 0.003 \\
\hline Select function & 12.8 & 7.4 & 4.7 & 3.2 & 10.4 & 0.0001 \\
\hline Select file & 19.6 & 10.4 & 12.3 & 6.3 & 19.1 & 0.0001 \\
\hline Default values & 11.8 & 1.3 & 5.4 & 1.3 & 4.9 & 0.0001 \\
\hline Dialogue levels & 22.6 & 11.2 & 7.4 & 4.3 & 8.0 & 0.0001 \\
\hline Edit search query & 21.3 & 4.3 & 6.8 & 2.9 & 11.9 & 0.0001 \\
\hline Combine commands & 16.5 & 3.2 & 3.5 & 1.4 & 4.3 & 0.0001 \\
\hline Refine search statement & 19.7 & 1.3 & 3.8 & 0.8 & 3.0 & 0.0001 \\
\hline \multicolumn{7}{|l|}{ Area II } \\
\hline Access to authority catalog & 4.0 & 4.6 & 0.3 & 0.8 & 0.5 & 0.0001 \\
\hline Free text search in selected fields & 24.5 & 13.9 & 11.5 & 9.2 & 27.7 & 0.0001 \\
\hline Free text search in entire record & 23.3 & 11.5 & 12.6 & 6.7 & 16.6 & 0.0001 \\
\hline Restrict search results & 22.5 & 4.9 & 5.1 & 3.0 & 7.6 & 0.0001 \\
\hline Boolean search & 23.3 & 11.7 & 14.2 & 6.2 & 15.7 & 0.0001 \\
\hline Boolean search in selected fields & 22.9 & 10.9 & 11.9 & 5.5 & 13.8 & 0.0001 \\
\hline Boolean search in entire record & 21.6 & 8.6 & 10.5 & 4.3 & 8.6 & 0.0001 \\
\hline Relational operators & 6.6 & 2.4 & 1.4 & 1.1 & 0.9 & 0.0001 \\
\hline Truncation & 18.2 & 4.6 & 7.6 & 2.7 & 7.0 & 0.0001 \\
\hline Proximity operators & 12.2 & 2.1 & 1.9 & 1.6 & 1.1 & 0.0001 \\
\hline \multicolumn{7}{|l|}{ Area III } \\
\hline Select a format for display & 20.4 & 10.2 & 7.7 & 4.6 & 6.2 & 0.0001 \\
\hline Select records & 23.6 & 13.4 & 8.1 & 7.2 & 19.8 & 0.0001 \\
\hline Select results order & 21.1 & 5.4 & 1.9 & 3.2 & 3.3 & 0.0001 \\
\hline Print results online & 13.0 & 8.6 & 5.9 & 2.4 & 7.5 & 0.0001 \\
\hline Save and/or mail results & 20.6 & 4.8 & 2.4 & 2.4 & 4.0 & 0.0001 \\
\hline \multicolumn{7}{|l|}{ Area IV } \\
\hline List of files & 12.3 & 8.5 & 9.0 & 4.9 & 11.0 & 0.0001 \\
\hline List of access points & 21.9 & 10.3 & 8.8 & 7.1 & 16.1 & 0.0001 \\
\hline Index terms & 20.9 & 7.8 & 9.0 & 2.5 & 6.8 & 0.0001 \\
\hline Search history & 19.0 & 0.6 & 1.7 & 1.0 & 1.9 & 0.0001 \\
\hline Item location & 24.6 & 14.2 & 14.6 & 9.8 & 26.7 & 0.0001 \\
\hline Item availability & 21.4 & 10.1 & 3.4 & 5.8 & 10.4 & 0.0001 \\
\hline System messages & 23.5 & 10.8 & 7.9 & 7.3 & 17.0 & 0.0001 \\
\hline Procedural prompts & 8.7 & 3.8 & 5.2 & 1.1 & 6.3 & 0.0001 \\
\hline Help messages & 20.9 & 6.2 & 6.3 & 3.9 & 6.0 & 0.0001 \\
\hline
\end{tabular}

Table 6: Chi-square test: Type of software vs. Functionalities $\mathrm{I}=$ International $\mathrm{R}=$ Regional $\mathrm{IS}=\mathrm{ISIS} \mathrm{O}=$ Others $\mathrm{U}=$ Unidentified 
where "Others" had a higher percentage of presence. Thus, stratum "Unidentified" got higher results than "ISIS" and "Others" in 4 out of 5 functionalities.

Area IV facilitated the identification of variables that were highly associated with the type of software implemented. Functionalities such as browsing index terms, giving access to search history, reporting item availability and providing online help were found to be considerably different between "International" and the other categories. Besides, the presence of all functionalities involved in the area was found in all with the exception of "Item location" which was associated with international software. There even was observed a closer relationship between international software and unidentified software than with the rest in the variables "List of files", "List of access points", "System messages" and "Procedural prompts".

In the four areas studied, international software behaved homogeneously with regard to the presence of functionalities in the OPAC interface. In the other strata their presence could be found at a lower level. A dissimilar and heterogeneous behavior was observed in the categories "Regional", "ISIS", "Others" and "Unidentified". There was also a very low presence of functionalities which could improve and refine searches.

Moreover, highly significant differences $(p<0.0001)$ were verified in countries represented by 30 or more units in relation to the type of software they had adopted. In correspondence with the association between this variable and applications in OPACs interfaces, it was feasible to infer that countries with a higher rate of international integrated library systems offered users a greater number of capabilities (Table 7).

Mexico was the country with the highest rate of integrated library systems followed by Brazil (where regional software reinforced this characteristic) and Colombia was third. Argentina was at the opposite end with a high use of "ISIS" and "Unidentified" software which clearly restricted online searches through the OPAC. Chile, like Colombia, was in an intermediate position with respect to most of the proposed types of software and even slightly better than Brazil regarding the use of international software. Peru and Venezuela were in a poor situation concerning the use of ILS.

These results led the research group to evaluate the convenience of using discriminant analysis to see the relationship among the four dimensions under study (represented by the frequency of appearance of the attributes of each one of the defined areas) with the "type of software" variable.

It was noted that $55.4 \%$ of the original grouped cases had been well classified, according to the proposed categories of software (Figure 1 and Table 8). Percentages that were obtained showed that "International" as well as "Unidentified" software were clearly different from the rest. It was therefore concluded that the reason for this was that the former (International) were ILS that included most of the analyzed functions. Instead, software that could not be identified during the data collection period usually had interfaces with minimal 


\begin{tabular}{l|c|c|c|c|c|c|c|c}
\hline $\begin{array}{l}\text { Type of } \\
\text { Software }\end{array}$ & Argentina & Brazil & Chile & Colombia & Peru & Venezuela & Mexico & Total \\
\hline International & 1.3 & 3.0 & 3.2 & 3.8 & 0.5 & 0.3 & 12.5 & 24.4 \\
\hline Regional & 0.6 & 5.4 & 0.2 & 0.8 & 0 & 3.2 & 4.1 & 14.2 \\
\hline ISIS & 9.3 & 2.5 & 1.7 & 1.1 & 1.7 & 0 & 0.3 & 16.7 \\
\hline Others & 0 & 4.9 & 1.9 & 1.3 & 0.6 & 0.5 & 1.4 & 10.6 \\
\hline Unidentified & 8.5 & 7.4 & 4.3 & 3.2 & 5.8 & 1.4 & 3.5 & 34.1 \\
\hline Total & 19.7 & 23.2 & 11.2 & 10.1 & 8.7 & 5.4 & 21.8 & 100 \\
\hline
\end{tabular}

Table 7: Type of software vs. Countries

functionalities and a performance that was quite different from properly developed ILS or DBMS systems.

Even when figures showed that some "ISIS" software designs had achieved some characteristics that were similar to an ILS interface, $74.1 \%$ was near the lowest performance category. Likewise, the category "Others" included several software designs that could have been an ILS as well as a DBMS but with a different level of complexity. The analyzed cases were associated with the characteristics of the categories: "International" and "Regional" in a lower percentage and "Unidentified" in a higher percentage. It was therefore concluded that most of these initiatives had not expanded their functionalities.

Besides, it was possible to verify that $51.2 \%$ of regional developments fell into categories represented by ILS while $48.8 \%$ fell into the "Unidentified" category. These percentages showed that the region was in an intermediate situation that included not only cases with the necessary capability to support solid designs but initiatives with limited operative possibilities as well.

However, when analyzing the situation in Mercosur member and associate countries (Figure 2 and Table 9) 56.9\% of regional software was correctly classified and $23.1 \%$ had blended "ISIS" and DBMS. This displayed a greater presence of functionalities in South American designs over those of Central American countries with fewer capabilities.

With the aim of improving prediction, "ISIS" and "Others" under the variable "Type of Software" were merged into one group ("ISIS" + "Others") with discriminant analysis being once again performed (Table 10). It was then observed that the percentage of those correctly classified improved in this category and that regional software had moved towards the new group. The percentage of software classified as "International" kept constant while there was a migration of those classified as "Unidentified" towards "ISIS" + "Others". Even so, the percentage of cases correctly grouped (57.1\%) rose slightly in relation to the initial cluster. 
332 Elsa Barber et al.

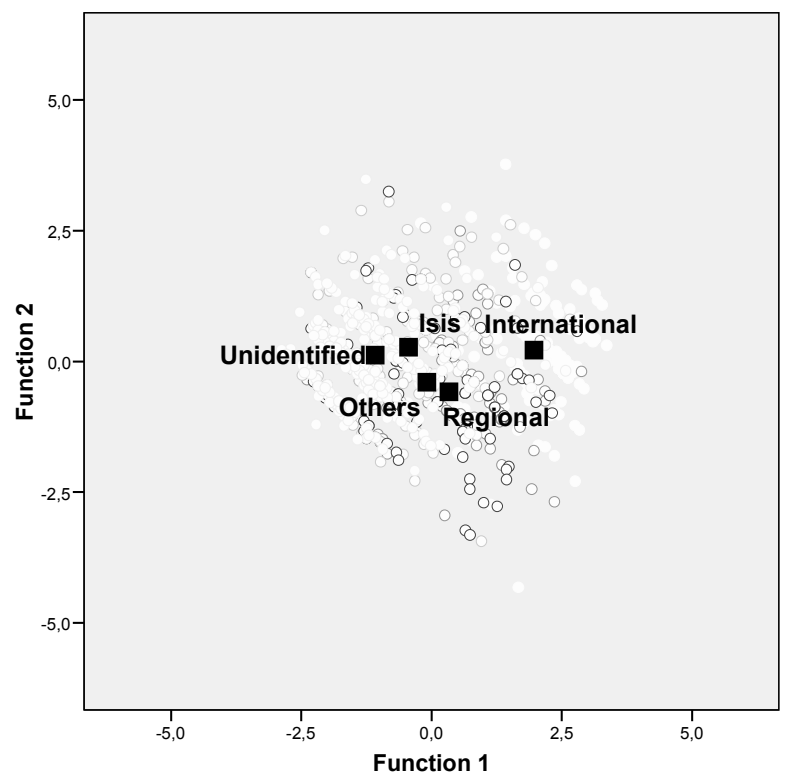

Figure 1: Discriminant analysis, Latin America - 5 software categories

\begin{tabular}{|c|c|c|c|c|c|c|c|}
\hline & $\begin{array}{l}\text { Software } \\
\text { categories }\end{array}$ & $\begin{array}{c}\text { Predicted } \\
\text { group } \\
\text { membership }\end{array}$ & & & & & \\
\hline \multirow{4}{*}{ Frequency } & & I & $\mathrm{R}$ & IS & $\mathrm{O}$ & $\mathrm{U}$ & Total \\
\hline & International & 151 & 11 & 2 & 0 & 13 & 177 \\
\hline & Regional & 24 & 38 & 0 & 0 & 59 & 121 \\
\hline & ISIS & 26 & 4 & 6 & 0 & 103 & 139 \\
\hline \multirow{7}{*}{ Percentage } & Others & 14 & 27 & 1 & 0 & 67 & 109 \\
\hline & Unidentified & 14 & 8 & 4 & 0 & 274 & 300 \\
\hline & International & 85.3 & 6.2 & 1.1 & 0 & 7.3 & 100.0 \\
\hline & Regional & 19.8 & 31.4 & .0 & , 0 & 48.8 & 100.0 \\
\hline & ISIS & 18.7 & 2.9 & 4.3 & , 0 & 74.1 & 100.0 \\
\hline & Others & 12.8 & 24.8 & .9 & 0 & 61.5 & 100.0 \\
\hline & Unidentified & 4.7 & 2.7 & 1.3 & 0 & 91.3 & 100.0 \\
\hline
\end{tabular}

Table 8: Discriminant analysis, Latin America - 5 software categories

$55.4 \%$ of originally grouped cases were correctly classified.

$\mathrm{I}=$ International $\mathrm{R}=$ Regional IS $=$ ISIS O $=$ Others $\mathrm{U}=$ Unidentified 


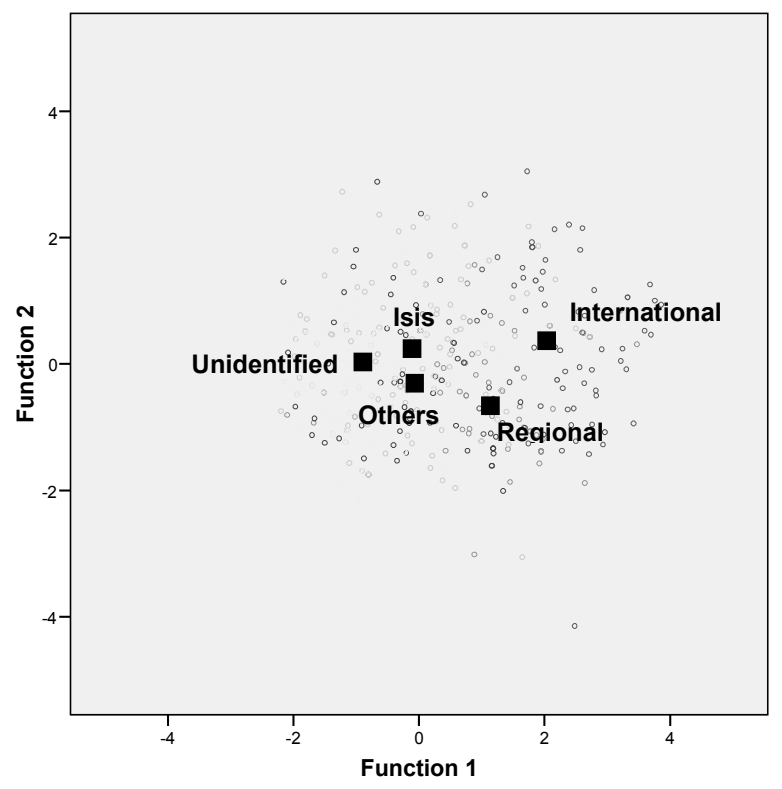

Figure 2: Discriminant analysis, Mercosur - 5 software categories

\begin{tabular}{|c|c|c|c|c|c|c|c|}
\hline \multirow{6}{*}{ Frequency } & $\begin{array}{l}\text { Software } \\
\text { categories }\end{array}$ & $\begin{array}{l}\text { Predicted } \\
\text { group } \\
\text { membership }\end{array}$ & & & & & \\
\hline & & I & $\mathrm{R}$ & IS & $\mathrm{O}$ & $\mathrm{U}$ & Total \\
\hline & International & 54 & 11 & 6 & 0 & 6 & 77 \\
\hline & Regional & 6 & 37 & 15 & 0 & 7 & 65 \\
\hline & ISIS & 11 & 7 & 25 & 1 & 73 & 117 \\
\hline & Others & 3 & 15 & 6 & 0 & 47 & 71 \\
\hline \multirow{6}{*}{ Percentage } & Unidentified & 4 & 6 & 13 & 1 & 213 & 237 \\
\hline & International & 70.1 & 14.3 & 7.8 & .0 & 7.8 & 100.0 \\
\hline & Regional & 9.2 & 56.9 & 23.1 & .0 & 10.8 & 100.0 \\
\hline & ISIS & 9.4 & 6.0 & 21.4 & .9 & 62.4 & 100.0 \\
\hline & Others & 4.2 & 21.1 & 8.5 & .0 & 66.2 & 100.0 \\
\hline & Unidentified & 1.7 & 2.5 & 5.5 & .4 & 89.9 & 100.0 \\
\hline
\end{tabular}

Table 9: Discriminant analysis, Mercosur - 5 software categories $58 \%$ of originally grouped cases were correctly classified. $\mathrm{I}=$ International $\mathrm{R}=$ Regional $\mathrm{IS}=$ ISIS O $=$ Others $\mathrm{U}=$ Unidentified 


\begin{tabular}{|c|c|c|c|c|c|c|}
\hline & $\begin{array}{l}\text { Software } \\
\text { categories }\end{array}$ & $\begin{array}{c}\text { Predicted } \\
\text { group } \\
\text { membership }\end{array}$ & & & & \\
\hline \multirow{4}{*}{ Frequency } & & I & $\mathrm{R}$ & $\mathrm{IS}+\mathrm{O}$ & $\mathrm{U}$ & Total \\
\hline & International & 149 & 6 & 16 & 6 & 177 \\
\hline & Regional & 17 & 13 & 56 & 35 & 121 \\
\hline & ISIS + Others & 32 & 12 & 77 & 127 & 248 \\
\hline \multirow{5}{*}{ Percentage } & Unidentified & 11 & 1 & 44 & 244 & 300 \\
\hline & International & 84.2 & 3.4 & 9.0 & 3.4 & 100.0 \\
\hline & Regional & 14.0 & 10.7 & 46.3 & 28.9 & 100.0 \\
\hline & ISIS + Others & 12.9 & 4.8 & 31.0 & 51.2 & 100.0 \\
\hline & Unidentified & 3.7 & .3 & 14.7 & 81.3 & 100.0 \\
\hline
\end{tabular}

Table 10: Discriminant analysis, Latin America - 4 software categories

$57.1 \%$ of originally grouped cases were correctly classified.

$\mathrm{I}=$ International $\mathrm{R}=$ Regional $\mathrm{IS}=$ ISIS $\mathrm{O}=$ Others $\mathrm{U}=$ Unidentified

The level of ambiguity that was observed after conducting the first and second clustering, began to disappear when categories "ISIS", "Others" and "Unidentified" were grouped (Figure 3 and Table 11). The percentage of software correctly classified rose to $78.1 \%$. "International" software showed a slight variation even when a $15.8 \%$ (previously dispersed) was identified, due to their functionalities, they became associated with the new group. The most significant fact was observed in the regional software category where the regrouped cluster obtained the $88.4 \%$.

There was strong contrast in user interface in regional software when the same statistical analysis was applied to the area restricted to Mercosur member and associate countries (Figure 4 and Table 12). First, software that classified correctly rose to $83.4 \%$ in the original cluster; secondly, $41.5 \%$ of regional software classified in their actual group.

A final regrouping was proposed (Table 13) between integrated software on one side ("International" + "Regional") and systems whose performance was non-integrated on the other ("ISIS" + "Others" + "Unidentified"), and it was confirmed that $83 \%$ of cases were correctly classified. This percentage was higher in the "Non-integrated" group (91.2\%). Besides, it was possible to distinguish that the $32.2 \%$ performance of the integrated software was not "integrated". It was therefore deduced that these cases belonged to "Regional" software as they had been previously wrongly classified. 


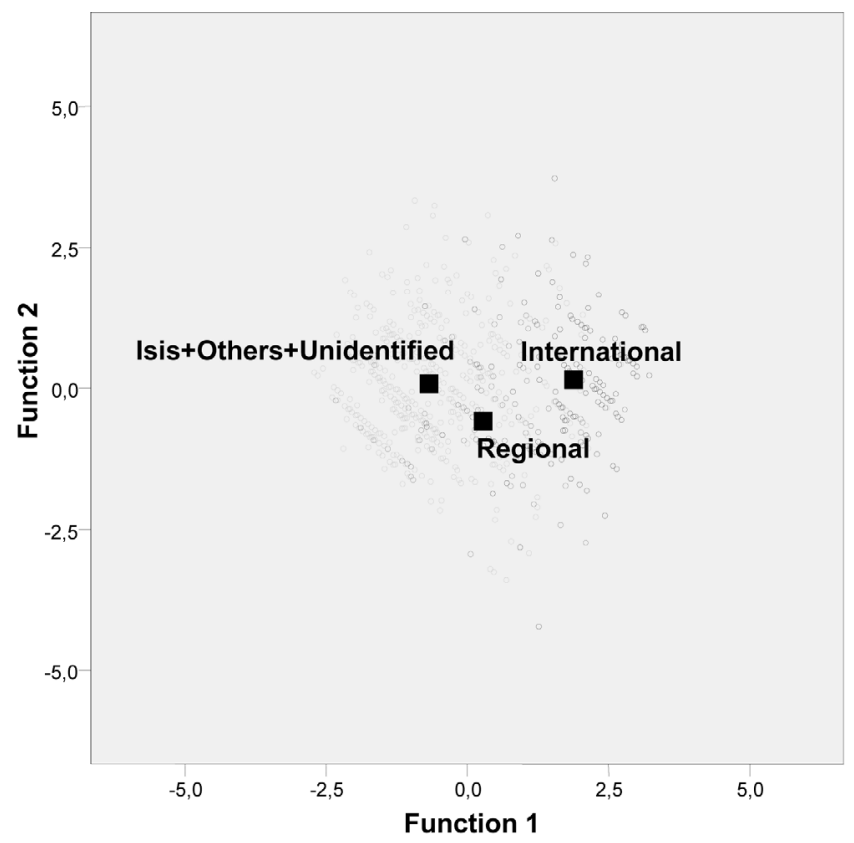

Figure 3: Discriminant Analysis, Latin America - 3 software categories

\begin{tabular}{|c|c|c|c|c|c|}
\hline \multirow{4}{*}{ Frequency } & $\begin{array}{l}\text { Software } \\
\text { categories }\end{array}$ & $\begin{array}{c}\text { Predicted } \\
\text { group } \\
\text { membership }\end{array}$ & & \multirow{3}{*}{$\begin{array}{c}\mathrm{IS}+\mathrm{O}+\mathrm{U} \\
28\end{array}$} & \multirow[b]{2}{*}{ Total } \\
\hline & & I & $\mathrm{R}$ & & \\
\hline & International & 147 & 2 & & 177 \\
\hline & Regional & 10 & 4 & 107 & 121 \\
\hline \multirow{4}{*}{ Percentage } & $\mathrm{IS}+\mathrm{O}+\mathrm{U}$ & 34 & 4 & 510 & 548 \\
\hline & International & 83.1 & 1.1 & 15.8 & 100.0 \\
\hline & Regional & 8.3 & 3.3 & 88.4 & 100.0 \\
\hline & $\mathrm{IS}+\mathrm{O}+\mathrm{U}$ & 6.2 & .7 & 93.1 & 100.0 \\
\hline
\end{tabular}

Table 11: Discriminant Analysis, Latin America - 3 software categories

$78.1 \%$ of originally grouped cases were correctly classified.

$\mathrm{I}=$ International $\mathrm{R}=$ Regional IS $=$ ISIS O $=$ Others $\mathrm{U}=$ Unidentified 


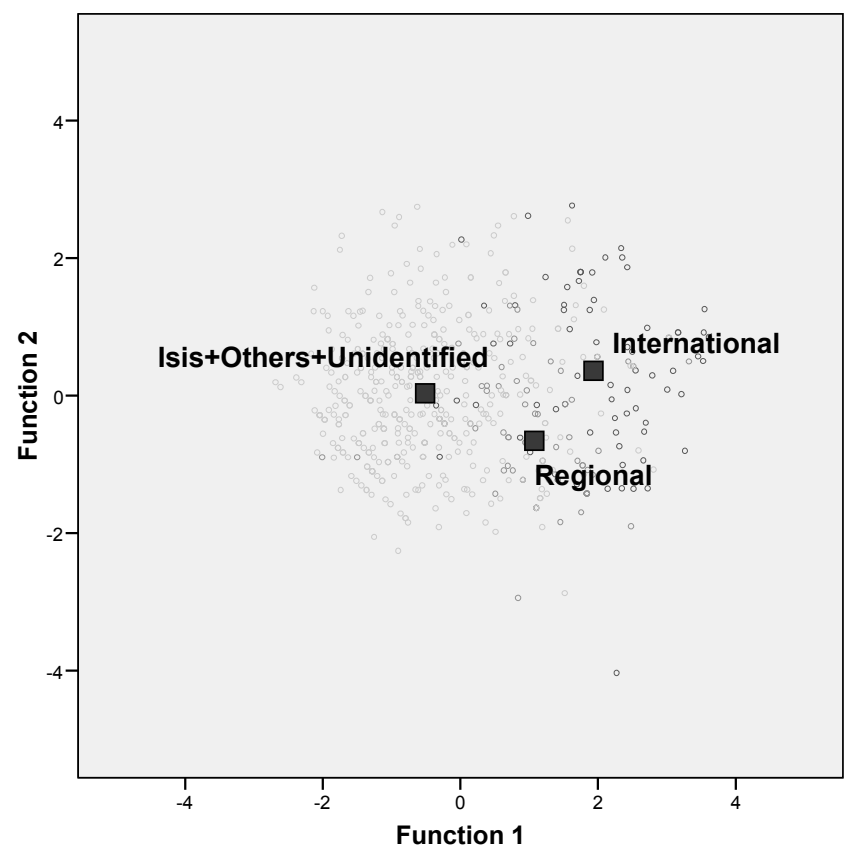

Figure 4: Discriminant Analysis, Mercosur - 3 software categories

\begin{tabular}{|c|c|c|c|c|c|}
\hline \multirow[b]{3}{*}{ Frequency } & \multirow[t]{2}{*}{$\begin{array}{l}\text { Software } \\
\text { categories }\end{array}$} & \multirow{2}{*}{$\begin{array}{c}\text { Predicted } \\
\text { group } \\
\text { membership } \\
\text { I }\end{array}$} & \multirow[b]{2}{*}{$\mathrm{R}$} & \multirow[b]{2}{*}{$\mathrm{IS}+\mathrm{O}+\mathrm{U}$} & \multirow[b]{2}{*}{ Total } \\
\hline & & & & & \\
\hline & International & 53 & 7 & 17 & 77 \\
\hline \multirow{5}{*}{ Percentage } & Regional & 5 & 27 & 33 & 65 \\
\hline & $\mathrm{IS}+\mathrm{O}+\mathrm{U}$ & 17 & 15 & 393 & 425 \\
\hline & International & 68.8 & 9.1 & 22.1 & 100.0 \\
\hline & Regional & 7.7 & 41.5 & 50.8 & 100.0 \\
\hline & $\mathrm{IS}+\mathrm{O}+\mathrm{U}$ & 4.0 & 3.5 & 92.5 & 100.0 \\
\hline
\end{tabular}

Table 12: Discriminant Analysis, Mercosur - 3 software categories

$83.4 \%$ of originally grouped cases were correctly classified.

$\mathrm{I}=$ International $\mathrm{R}=$ Regional $\mathrm{IS}=$ ISIS $\mathrm{O}=$ Others $\mathrm{U}=$ Unidentified 


\begin{tabular}{|c|c|c|c|c|}
\hline & $\begin{array}{l}\text { Software } \\
\text { categories }\end{array}$ & $\begin{array}{c}\text { Predicted } \\
\text { group } \\
\text { membership }\end{array}$ & & \\
\hline \multirow{3}{*}{ Frequency } & & I & N I & Total \\
\hline & Integrated & 202 & 96 & 298 \\
\hline & Non integrated & 48 & 500 & 548 \\
\hline \multirow[t]{2}{*}{ Percentage } & Integrated & 67.8 & 32.2 & 100.0 \\
\hline & Non integrated & 8.8 & 91.2 & 100.0 \\
\hline
\end{tabular}

Table 13: Discriminant Analysis, Latin America - 2 software categories

$83 \%$ of originally grouped cases were correctly classified.

$\mathrm{I}=$ Integrated N I = Non Integrated

This geographical study revealed the prevalence of systems that were seriously disadvantaged to fulfill users' needs for information, searching and retrieval. The study also indicated all the difficulties that libraries face in order to install functional ILS systems. These difficulties were present not only in the libraries surveyed but they are also generally present throughout Latin American countries. The study indicates what libraries in the region that were researched have to overcome in order to offer local solutions in the light of international developments.

\section{Conclusion}

The survey indicated that in Latin American libraries, most of the functionalities selected for this study were absent in the user interfaces of OPACs. When comparing by type of software through multiple discriminant analysis, the previously observed association between functionalities and type of software became more pronounced. Additionally, it was also possible to verify the ability of the selected variables to describe and distinguish between identified software categories. Subsequently, it was possible to acknowledge the capability of functionalities and to predict the type of software. Therefore, it could be objectively deduced that the software used by Latin American libraries influences the search and retrieval services offered to users through their OPACs. 
Additionally, it was frequently observed that information units had not fully developed software functionalities and in most cases, they had difficulties with implementing appropriate library management systems. After comparing the results of discriminant analysis in Mercosur and Latin American countries, it was also noticed that, even when the general trend was similar for the Latin American region, there were some differences between South and Central America in interface functionalities of locally developed OPACs. Since the international trend in libraries is towards the design of systems under the Web 2.0 philosophy on the basis of ILS, based on the variety of options observed in the implementation of this type of software in the countries surveyed it would be useful for institutions in the countries surveyed to bear in mind these findings in any plans they may have to migrate to OPAC 2.0.

The difficulties that were found reflected the limitations faced by researchers, teachers, government officials and citizens to identify the corpus of knowledge produced and/or available in the region. If libraries are considered a place to access knowledge and institutions that can guarantee an ethical and democratic use of information which can foster scientific, technical and cultural development, some attention will have to be paid to software and functionalities to be offered not only in OPACs but also in future portals and Web 2.0 OPACs that provide integrated and collaborative access to information resources.

\section{References}

Abadal Falgueras, E. "Elementos para la evaluación de interfaces de consulta de bases de datos." El Profesional de la Información, 11.5 (2002): 349-360.

Arant, W. and Payne, L. "The common user interface in academic libraries: Myth or reality?" Library Hi Tech, 19.1 (2001): 63-73.

Ayres, F. H., Nielsen, L. P. S. and Ridley, M. J. "BOPAC2: A new concept in OPAC design and bibliographic control." Cataloging and Classification Quarterly, 28.2 (1999): 1744.

Badu, B. R. and O'Brien, A. "Web OPAC interfaces: An overview." The Electronic Library, 18.5 (2000): 316-327.

Barber, E., et al. "Information society and information technology: The situation of the public libraries in Buenos Aires city and surrounding areas, Argentina." International Information and Library Review, 38.1 (2006): 1-14.

Barber, E., et al. "Los catálogos en línea de acceso público disponibles en entorno Web en Argentina y Brasil: diagnóstico de situación." La interdisciplinariedad y la transdisciplinariedad en la organización del conocimiento científico = Interdisciplinarity and transdisciplinarity in the organization of scientific knowledge. Actas del VIII Congreso ISKO - España, León 18, 19 y 20 de Abril de 2007. León: Universidad de León, (2007a).

-. "Los catálogos en línea de acceso público del Mercosur como soporte a la innovación." XII Seminario Latino - Iberoamericano de Gestión Tecnológica - ALTEC 2007, Buenos Aires, 26-28 de 2007. (2007b). 
Barber, E., et al. "Los catálogos en línea de acceso público del Mercosur disponibles en entorno Web." Información, Cultura y Sociedad, 18. 2008. www.scielo.org.ar/pdf/ics/n18/n18a03.pdf [Mar. 2011].

Bates, M. J. OPAC Use and Users: Breaking Out of the Assumptions. Chicago: American Library Association, 1991. (Occasional Papers, n. 9)

Beaulieu, M. "Interaction in information searching and retrieval." Journal of Documentation, 56.4: (2000): 431-439.

Beaulieu, M. and Borgman, C. L. "A new era for OPAC research: Introduction to special topic issue on current research in online public access systems." Journal of the American Society for Information Science, 47.7 (1996): 491-492.

Beheshti, J. "The future of OPAC interfaces." ALA/CLA Annual Conference, Optimal Design Considerations for Web OPAC Interfaces. A program sponsored by LITA, June 22, 2003, Toronto. 2003. www.calstatela.edu/library/ALA/ala-claOPAC.htm [Mar. 2011].

Beheshti, J., Large, V. and Bialek, M. "PACE: A browsable graphical interface." Information Technology and Libraries, 15.4 (1996): 231-240.

Borgman, C. L. "Why are online catalogs still hard to use?" Journal of the American Society for Information Science, 47.7 (1996): 493-503.

Boss, R. W. Library Portals. Chicago: American Library Association. 2005. www.ala.org/ala/pla/plapubs/technotes/librarywebportals.htm [Mar. 2011].

Byrum, J. D. "Online catalogs and library portals in today's information environment." Journal of Library Administration, 43.1/2 (2005): 135-154.

Carlyle, A. "Ordering author and work records: An evaluation of collocation in online catalog displays." Journal of the American Society for Information Science, 47.7 (1996): 538-554.

Carlyle, A and Timmons, T. Default Record Displays in Web-Based Catalogs. Chicago: University of Chicago. 2002. http://faculty.washington.edu/acarlyle/Papers/default_displays.htm [Mar. 2011].

Cherry, J. M. and Cox, J. P. World Wide Web displays of bibliographic records: An evaluation. 1996.

http://www3.fis.utoronto.ca/research/programs/displays/caispck1.htm [Mar. 2011].

Chiang, D. "Comparison of direct manipulation, menu selection, and command language as interaction styles for online public access catalogs." Dillon, M., ed. Interfaces for Information Retrieval and Online Systems: The State of the Art. New York: Greenwood Press, 1991.

Clifford, A. L. "The use of heuristics in user interfaces for online information retrieval systems." ASIS '87, Proceedings of the 50 ${ }^{\text {th }}$ ASIS Annual Meeting, 24 (1987): 148-152.

Culkin, P. B. "Rethinking OPACS: The design of assertive information systems." Information Technology and Libraries, 8.2 (1989): 172-177.

Delsey, T. "The library catalog in a networked environment." Proceedings of the Bicentennial Conference on Bibliographic Control for the New Millennium: Confronting the Challenges of Networked Resources and the Web. Washington, D.C.: Cataloging Distribution Service, 2001. www.loc.gov/catdir/bibcontrol/delsey_paper.html [Mar. 2011].

Dorner, D. G. and Curtis, A. M. A comparative review of common user interface software products for libraries. 2003.

www.natlib.govt.nz/catalogues/library-documents/common-user-interface-software [Mar. 2011]. 
Dowling, T. "The World Wide Web meets the OPAC: from catalogs to Gateway." Briefings from the CFFC, (9), A-D. Published by the American Library Association as a supplement to the ALCTS Newsletter, 8.2 (1997).

Frost, C. O. "Next generation online public access catalogs: Redefining territory and roles." Advances in Library Automation and Networking, 5 (1994): 1-41.

Gremett, P. "Utilizing a user's context to improve search results." Journal of the American Society for Information Science and Technology, 57.6 (2006): 808-812.

International Federation of Library Associations and Institutions. Guidelines for Online Public Access Catalogue (OPAC) Displays. Draft for worldwide review. 2003. www.ifla.org/VII/s13/guideopacguide03.pdf [Mar. 2011].

Henry, H. K. "Human-computer interfaces and OPACs: Introductory thoughts related to INNOPAC." Library Hi Tech, 9.2 (1991): 63-68.

Herrero-Solana, V. and Moya-Anegón, F. de. "Bibliographic displays of Web-based OPACs: Multivariate analysis applied to Latin-American catalogues." Libri, 51.2 (2001): 75-85.

Hildreth, C. R. Online Public Access Catalogs: The User Interface. Dublin, OH: OCLC, 1982.

-. "Online public access catalogs." Annual Review of Information Science and Technology, 20 (1985): 233-285.

-. "Beyond Boolean: Designing the next generation of online catalogs." Library Trends, 35.4(1987): 647-667.

-. "Online library catalogues as information retrieval systems: What can we learn from research?" Yates-Mercer, P. A., ed. Future Trends in Information Science and Technology. Proceedings of the Silver Jubilee Conference of the City University's Department of Information Science, January 16, 1987. London: Taylor Graham, 1988.

-. (1995) "On-line catalog design models: Are we moving in the right direction?" A report prepared for the on Council Library Resources. 1995.

http://www.ou.edu/faculty/H/Charles.R.Hildreth/clr-five.html [Mar. 2011].

-. "Accounting for users' inflated assessments of on-line catalogue search performance and usefulness: An experimental study." Information Research, 6.2. 2001. http://informationr.net/ir/6-2/paper101.html [Mar 2011].

IFLA. IFLA Statement of International Cataloguing Principles. 2009. http://www.ifla.org/publications/statement-of-international-cataloguing-principles [Mar. 2011].

Játiva Miralles, M. V. El Profesional de la Información, 13.1 (2004): 28-46.

Kaske, N. K. and Ferguson, D. On-Line Public Access to Library Bibliographic Data Bases: Developments, Issues and Priorities. Columbus, OH: Research Libraries Group, OCLC, (1980).

Komlodi, A., Soergel, D. and Marchionini, G. "Search histories for user support in the user interfaces." Journal of the American Society for Information Science and Technology, 57.6 (2006): 803-807.

Large, J. A. and Beheshti. J. “OPACs: A research review.” Library and Information Science Research, 19.2 (1997): 111-133.

Larson, R. R., McDonough, J., O'Leary, P. and Kuntz, L. "Cheshire II: Designing a nextgeneration online catalog." Journal of the American Society for Information Science, 47.7 (1996): 555-567.

Library of Congress. Portals Applications Issues Group. 2005. www.loc.gov/catdir/lcpaig [Mar. 2011]. 
Martínez-Arellano, F. F. "User attitudes and behavior before and after the implementation of an online catalog", The International Information \& Library Review, 28.3 (1996): 275-287.

Matthews, J. R. (1982) Public Access to Online Catalogs: A Planning Guide for Managers. Weston, CT: Online, 1982.

McGarry, D. and Svenonius, E. "More on improved browsable displays for online subject access." Information Technology \& Libraries, 10.3 (1991): 185-191.

Meadow, C. T., et al. Text Information Retrieval Systems. $3^{\text {rd }}$ ed. Amsterdam: Elsevier, Academic Press, 2007.

Ortíz Repiso, V. and Moscoso, P. "Web-based OPACs: Between tradition and innovation." Information Technology and Libraries, 18.2 (1999): 68-77.

Ramesh Babu, B. and Tamizhchelvan, M. "An investigation into the features of OPACs in Tamil Nadu (India." Library Review, 52.5/6 (2003): 257-267.

Rodríguez Yunta, L. and Giménez Toledo, E. "Lo que los usuarios piensan de las bases de datos bibliográficas y no se atreven a decir. ¿Es posible un diseño centrado en el usuario?" Preprint de la primera versión de la Comunicación enviada a Infogestión, IX Jornadas Españolas de Documentación, Fesabid, 14-15 Abril, 2005. 2005. http://eprints.rclis.org/handle/10760/5783 [Mar. 2011].

Shneiderman, B. Designing the User Interface: Strategies for Effective Human-ComputerInteraction. $3^{\text {rd }}$ ed., Reading, Massachusetts: Addison-Wesley, 1998.

Stevens, N. D. "Looking back at looking ahead, or 'The catalogs of the future revisited' with additional speculation." Information Technology and Libraries, 17.4 (1998): 188190.

Thomas, S. E. "The catalog as portal to the Internet." Bicentennial Conference on Bibliographic Control for the New Millennium: Confronting the Challenges of Networked Resources and the Web. 2000. www.loc.gov/catdir/bibcontrol/thomas_paper.html [Mar. 2011].

Villén-Rueda, L., Senso, J. A. and Moya-Anegón, F. de "The use of OPAC in a large academic library: A transactional log analysis study of subject searching." Journal of Academic Librarianship, 33.3 (2007): 327-337.

Wildemuth, B. M. "Evidence-based practice in search interface design." Journal of the American Society for Information Science and Technology, 57.6 (2006): 825-828.

Williams, B. K., Sawyer, S. C. and Hutchinson, S. E. Using information technology: A practical introduction to computers and communications. Chicago: Irwin, 1995.

Williams, M. E., et al. (1986) "Comparative analysis of online retrieval interfaces." Proceedings of the $49^{\text {th }}$ ASIS Annual Meeting, 23 (1986): 365-370.

Williamson, N. J. "Is there a catalog in your future? Access to information in the year 2006." Library Resources \& Technical Services, 26.2 (1982) 122-135.

Yee, M. M. "System design and cataloguing meet the user: User interfaces to online public access catalogs." Journal of the American Society for Information Science, 42.2 (1991): $78-98$.

-. (1998) "Guidelines for OPAC displays." Prepared for the IFLA Task Force on Guidelines for OPAC Displays. $1998 \mathrm{http} / /$ archive.ifla.org/VII/s13/guide/opacguide03.pdf [Mar. 2011].

Yee, M. M. and Layne, S. S. Improving online public access catalogs. Chicago: American Library Association, 1998.

Zumer, M. and Zeng, L. "Comparison and evaluation of OPAC end-user interfaces." Cataloging \& Classification Quarterly, 19.2 (1994): 67-98. 
